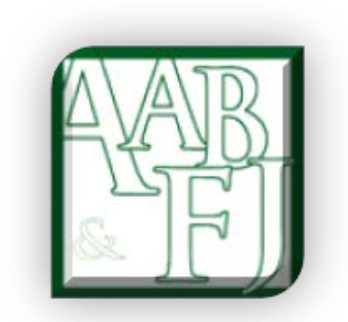

\title{
Accounting for Heritage, Cultural and Community Assets - Alternative Metrics from a New Zealand Māori Educational Institution
}

\author{
Susan Wild ${ }^{1 *}$
}

\begin{abstract}
In the 1980s, with the rise to dominance of governments with neoliberal economic and social agendas, the public sector in major western countries underwent a process of fundamental reforms. A key aspect of the change imposed was the implementation of a market-oriented, cost-efficiency focus towards the management of public sector organisations, described collectively as the New Public Management (NPM) model (Kelsey, 1995; Boston et al, 1996; Easton 1996; Barton, 2002, 2005a, 2005b; Carnegie \& West, 2005; Ball \& Grubnic, 2008; Davis, 2010). This reform process included the imposition of regulatory measures requiring public sector organisations to provide annual financial reports prepared on an accounting basis comparable to those for the private sector, and incorporated an obligation to disclose (at economic values) all assets held. For public benefit entities holding heritage, cultural and community assets (HCA), this reporting requirement has been particularly problematic, entailing substantive changes to public accounting policy.

This paper critiques the political ideologies and practices of the NPM model, and challenges its assumptions that private sector financial reporting requirements, based on international accounting standards and Generally Accepted Accounting Practice (GAAP), are appropriate for universal application to public benefit and other not-for-profit entities holding HCA. In particular, the paper argues against the NPM assumption that reporting all HCA in economic terms improves accountability in public benefit entities. Instead, the paper proposes an alternative reporting model based on a set of cultural rather than economic values for reporting HCA. It suggests as an exemplar the 'Wellbeing of Communities' reporting and accountability framework devised for application by an indigenous New Zealand Māori educational institution, Te Wānanga-o-Raukawa.
\end{abstract}

Keywords: Accountability; Accounting; Heritage and cultural assets; Māori; Public benefit entities. JEL Code: M40.

\footnotetext{
${ }^{1}$ University of Canterbury, New Zealand. * Susan.wild@canterbury.ac.nz
} 


\section{Introduction}

Heritage, cultural and community assets (HCA) comprise a very valuable tangible and intangible component of the economic, social, cultural and natural capital of many public sector entities. They contribute a significant qualitative value to communities in the form of enhancing social cohesiveness and national identity. They make a direct and indirect regional and national economic contribution (for example in attracting tourism revenue), and augment an international reputation (ACT, 2008; Carnegie \& West, 2005; ASB, 2006a; IFAC, 2006; Easton, 1997).

There is no definitive accounting or legal definition of HCA, and these vary widely in different contexts. Various classifications have included: collections of art, artefacts and specimens held in public galleries, museums, libraries and scientific and educational institutions; public gardens, iconic landholdings such as national parks, historic trees, streetscapes, vistas and landscapes; civic and historic buildings, public memorials, statues, fountains and sculptural works; historical memorabilia; and other tangible and intangible items which represent publicly expressed social and cultural interests and activities (IFAC, 2006; ASB, 2006a; ACCA, 2006; NZ IAS 16, para. 5.1; NZ Treasury, 2002).

Some analysis (for example Pallot, 1990, 1992; Micallef \& Peirson, 1997; ACT, 2008), introduces a further sub-category of HCA, that of community assets. Community assets are items of property, plant and equipment (PPE) that are provided by public benefit entities (PBEs) 'essentially for general community use or service' (ACT, 2008, 2.1.2). Such assets include: tangible assets such as rural recreational reserves and picnic/camping areas; nature reserves; national parks; urban parks and sports grounds; public infrastructural assets, land under public roads and rail systems (ACT, 2008, section 2.1.2); and intangible assets including copyrights and trademarks over publicly accessible creative works.

Other items of value generated within those PBEs whose purpose is the development and enhancement of cultural benefits to society generally - as in the case of educational, research, archival and scientific institutions, for example - include the cultural capital represented in the resources comprised within factors such as the quality and prestige of staff, reserves of specialist knowledge, institutional reputation, ability to attract research funding and sponsorship, and the value added towards human achievement, social benefit and quality of life produced by such organisations. As these 'assets' are internally generated and difficult to measure in economic terms, and although frequently representing significant 'value', they are not recognised in the financial statements of such organisations as they do not comply with the recognition criteria currently prescribed by conventional accounting practice.

In recent decades, the financial reporting of HCA has become a highly problematic issue for PBEs, who are required by regulation to report to stakeholders on a model disclosing economic values for all asset holdings and operations. PBEs are public sector and not-for-profit (NFP) organisations 'whose primary objective is to provide goods or services for a community or social benefit and where any equity has been provided with a view to supporting that primary objective rather than for the financial return to equity shareholders' (MED, 2009, section 100).

Prior literature indicates that current regulation in regard to the reporting requirements for PBEs, which focuses on the provision of financial information, is inadequate for ensuring the provision of information useful to the types of decisionmaking relevant to the needs of stakeholders in the case of of organisations holding HCA, and suggests that additional forms of information should be provided (see, for example, Pallot, 1990; Carnegie and Wolnizer 1997;Carnegie \& Wolnizer, 1995; 
Barton, 1999a; Jacobs, 2000; Hooper \& Kearins, 2005; Heslop \& van Staden, 2009; West \& Carnegie 2010).

While there exists an extensive prior literature focused on reporting HCA within a conventional accounting framework (see, for example, ACCA, 2006; Carlin, 2005; Price \& Smith, 2000; Thompson, 1998; Hone, 1997; Stanton \& Stanton, 1997; Rowles, 1991; Currie, 1987; Huggins, 1983; Mautz, 1981; Hofstede, 1981), there is little that addresses the valuation and reporting of such assets from an alternative, non-financial perspective. In order to gain potential insights for the purpose of developing an alternative, more comprehensive reporting model relevant to such organisations, this paper analyses the public documents provided by the New Zealand Māori educational organisation Te Wānanga-o-Raukawa. These documents disclose that a broad-ranging approach is taken towards reporting information for societal stakeholders that includes a range of cultural values and organisational achievements as well as financial indicators. This organisation reports comprehensively on its cultural position and performance, incorporating qualitative information on values in addition to mandated financial information (Te Wānanga-o-Raukawa website). This approach adopts a broad interpretation of the term 'cultural assets', including both tangible and intangible measures of value.

Prior to the 1980s most public NFP entities were subject to only limited reporting obligations regarding their functions of stewardship of HCA (Easton, 1997; Lehman, 2001; Hooper \& Kearins, 2005). Commonly, they were required to account for funds employed in the acquisition, maintenance, extension, replacement, and disposal of such assets, and to report on their 'operations' for specified stakeholders (usually limited to government ministries), using a range of means for 'valuing' the HCA held under their stewardship. These typically included a variety of qualitative and quantitative non-financial measures such as records of visitor numbers and approval ratings, specialist reviews, invitations to participate in inter-country exhibitions, international reputation, collections cited in scholarly works, and peer esteem of curators (Easton, 1997).

In recent decades, however, with the ascendancy to political power of governments advocating the neo-conservative ideology of the New Public Management (NPM) model of accountability, all public entities have been required to attribute economic values to HCA, and to produce annual financial reports prepared on an equivalent basis to the corporate model. During the 1980s and 1990s, the New Zealand (NZ) government, in line with others including Australia, the UK, and the US, enacted a range of legislative measures imposing fundamental changes on the structure and organisational objectives of the public sector. Most government entities were corporatised in their structure and governance, and many were subsequently privatised. Market-focused principles of management reoriented the primary function of public sector organisations towards the achievement of defined service outputs, economic outcomes and commercial practices, rather than traditional social goals. (Kelsey, 1995; Easton, 1997; Barton, 1999a, 2000; Boston, et al, 1996; Broadbent \& Guthrie, 1992; Carnegie \& Wolnizer, 1999). Among the range of major shifts in focus imposed on NFP PBEs, tertiary educational institutions were reoriented as service providers of private education benefits to fee-paying students, required to be responsive to market demand and to generate an alternative income to supplement their reduced government funding (Kelsey, 1995, p4).

While New Zealand was an early adopter of the NPM model, and did so extensively and with notable alacrity (Kelsey, 1995), similar changes were imposed in the UK, the US, Australia, and subsequently (to a more limited extent) in Canada 
(Easton, 1997), as well as many other countries. The complex issues of recognition, measurement and reporting of HCA have been increasingly exigent for public sector entities in these countries since the 1980s and 1990s, when changes in political attitudes towards the nature and purpose of such entities led to substantive changes in the regulatory environment within which they operated. The underlying intention of those driving public accounting reforms was to shift the ethos of the public service, and to radically reorient its function in society (see, for example, Gray, Owen \& Adams 1996; Easton, 1997; Feigenbaum \& Henig, 1994; Hofstede, 1981; Leat, 1988).

This paper analyses New Zealand's public sector reforms, in particular its implications for the accounting treatment of cultural assets. The approach towards these reforms implemented in New Zealand was appropriated from the neoliberal political and economic theories developed in the US and the UK, and that have since been adopted in full or part in other major western countries. It is therefore an appropriate proxy that is generalisable for the international issue of the politicisation of accounting in the case of PBEs holding cultural assets. The methodology used in the paper is that of critical analysis of the relevant literature, including the promulgations of accounting standard-setting agencies and related organisations. The paper analyses the requirements of current (conventional) methods of accounting for HCA, and critiques the ideologies of the NPM model, challenging its assumptions that private sector financial reporting requirements based on Generally Accepted Accounting Principles (GAAP), are appropriate for PBEs and other NFP entities, particularly in the case of accounting for HCA.

Instead, this paper proposes a reporting model based on alternative metrics for the recognition and measurement of such assets, centred upon a framework that suggests a set of broad stakeholder-driven social and cultural, rather than economic values. It uses as an exemplar the 'Wellbeing of Communities' (Winiata, 2006) reporting framework devised by New Zealand Māori educational institution Te Wānanga-o-Raukawa, based in Otaki, New Zealand (see the Te Wānanga-o-Raukawa website). This paper suggests that in the context of public sector entities holding HCA, including NPF educational institutions, such a conceptual framework provides a more relevant and useful measure of public accountability towards societal stakeholders. It proposes that the principles outlined in the 'Wellbeing of Communities' could be adapted as a framework applicable for wider use in PBE reporting.

\section{Background to Public Sector Reporting Changes}

Among other substantive regulatory changes imposed in New Zealand in the 1980s, the State Sector Act 1988 created the role of autonomous chief executive for public sector entities, displacing the previous position of apolitical permanent public service heads. The Public Finance Act 1989 (PFA) imposed an accrual-based financial accounting and reporting regime in accordance with GAAP in all public sector organisations, with the Local Government Act 2002 (LGA) setting specific reporting requirements in that sector. These initiatives were enacted in parallel with the Financial Reporting Act 1993 (FRA), which imposed on all 'issuers' (that is, entities that offered securities to the public, from both the private and public sectors), the obligation to provide annual financial statements in accordance with the applicable financial reporting standards. From 2004, these standards were harmonised with the financial reporting standards promulgated by the International Accounting Standards 
Board (IASB), bringing New Zealand's financial reporting regime in line with that of most major western countries.

These major changes in mandated reporting requirements for public sector organisations were based on the ideological assumption that, regardless of their societal role, such entities were to be considered fundamentally analogous in purpose and function to those of the private sector. In this view, public sector organisations were required to be structured, managed, controlled, and held accountable to stakeholders for their 'invested capital', in a manner largely comparable to those in the corporate sector, a political praxis underpinned by the theories and ideology of the NPM model. This represented a major shift in purpose and past modes of public sector reporting, and impacted upon the nature of the management of collections of HCA under the stewardship of public sector organisations and other NFP organisations, such as museums, art galleries, libraries, and the archival collections of universities and other educational institutions (Gray \& Bebbington, 2006; Gray, et al, 1996; Gray, 1983; O’Dwyer, 2003; West \& Carnegie, 2010).

Analysts including Guthrie (1993, 1998) and Davis (2010) illustrate the political implications of the change from a cash-based to an accrual-based reporting regime in the public sector. Accounting changes, including the incorporation of 'full costs' such as depreciation and amortisation into public sector reporting, contributed towards promoting the view that the public sector was inefficient in using invested funds in relation to private sector performance, and aided in legitimating the NPM ethos. Neo-liberal governments used the change to accrual-based reporting to support their NPM corporatisation and privatisation political agenda (Kelsey, 1995; Boston, et al, 1996; Easton, 1997; Pallot, 2001).

Since the 1980s, an extensive body of literature has focused on the political, economic and social implications of imposing a private sector management and reporting model onto PBEs. A major concern of the literature is its engagement in the argument regarding the nature of accountability as it applies to the public sector. A further argument in the literature strongly debates whether the requirement for PBEs to provide financial statements based on the private sector model impacts positively or negatively on public sector accountability outcomes (for example, Barton, 1999a; Booth \& Peterson, 1982; Carnegie \& Wolnizer, 1996; Carnegie \& West, 2005; Cooper \& Owen, 2007; Edwards \& Hulme, 1996; Gray, 1983; Gray \& Bebbington, 2006; Hofstede, 1981; Hone, 1997; Huggins, 1983; Kay \& Thompson, 1986; Leat, 1988; Micallef \& Peirson, 1997; O’Dwyer, 2008). Despite ongoing controversy over the past three decades, and disputed claims regarding the efficacy of the changes imposed, conventional accounting policy continues to support the reporting practices introduced by the NPM (IFRS17; NZ Treasury, 2002; UK Treasury, 2008; ASB, 2006a, 2006b; IFAC, 2001, 2006).

\section{Accounting for Heritage and Cultural Assets - Conventional Approaches}

Although HCA frequently constitute a considerable asset class for individual PBEs, both in economic and cultural terms, there exists no separate accounting standard mandating practice for their recognition, measurement, accounting treatment, reporting and evaluation of management accountability. There are various discussion papers, technical aids, academic treatises, and other guidelines for such accounting, but none prescribes definitive procedures. As a consequence, there is wide variation in the accounting treatment of HCA, both in regard to different classes of assets, different means of acquiring and funding asset types, differences in treatment based 
on the time of acquisition, and differences between organisations. Thus there is a high level of variability and subjectivity in the economic measurement of HCA.

This lack of consistency in the treatment of these assets contravenes fundamental accounting requirements that reported information should reflect qualitative characteristics of relevance, consistency, comparability and verifiability, and should 'faithfully represent what it purports to represent' (NZ Framework 2010, paragraph BC3.34), in order to be useful to stakeholders. It is a regulatory imperative in countries including the UK, Australia and New Zealand, among others, that all HCA should be reported in accordance with GAAP (for example ACCA, 2006), including conformity with the requirements of the relevant International Financial Reporting Standards (IFRS) and applicable accounting Framework. The NZ Framework 2010 (XRB, Framework, 2010) is the New Zealand equivalent to the IASB Conceptual Framework for Financial Reporting, 2010. NZ PBEs are currently subject to the provisions of Part B of the NZ Framework 2010. A recent change in the New Zealand accounting environment imposed by the NZ External Reporting Board (XRB) is that New Zealand will move to a regime of reporting standards for PBEs based on the modified International Public Sector Accounting Standards (IPSAS). These new standards for PBEs are currently under production by the XRB.

The NZ Framework 2010 (the 'Framework'), as it currently applies to PBEs, outlines the concepts that underlie the preparation and presentation of financial statements for external users, setting out the objectives of financial statements and the qualitative characteristics that determine the usefulness of information in the financial statements, including the 'definition, recognition and measurement of the elements from which financial statements are constructed' (Framework, paragraph B.5.c.). The Framework asserts that: '[t]he objective of financial reporting is to provide information about the financial position, performance, and changes in financial position of an entity that is useful to a wide range of users in making economic decisions' (paragraph B.12); '[f]inancial statements also show the results of the stewardship of management, or the accountability of management for the resources entrusted to it' (paragraph B.14); '[f]inancial statements prepared for this purpose meet the common needs of most users. ... However financial statements do not ... necessarily provide non-financial information' (paragraph B.13). The Framework further sets out the qualitative characteristics that such information should reflect. These qualities 'are the attributes that make the information provided in financial statements useful to users. The four principal qualitative characteristics are understandability, relevance, reliability and comparability' (paragraph B.24).

There is no single accepted legal or accounting definition of HCA, nor a single accounting standard that determines all aspects of their accounting treatment. Also, there are considerable conceptual differences between operational heritage assets (tangible PPE, such as land and buildings used in the operations of PBEs), and tangible and intangible cultural assets. These issues lead to considerable variation in the way PBEs report HCA.

The complexities inherent in defining and accounting for HCA are illustrated in the body of literature concerned with these issues that has arisen in response to the legislative and accounting requirements directed at public sector entities since the 1980s. The measurement and reporting of some types of heritage assets are particularly problematic, as, despite the fact that they undoubtedly represent 'value' to their stakeholders measured in cultural terms, this value frequently cannot be satisfactorily rendered in economic terms. The Framework requires that an asset is controlled by an entity, and is 'recognised in the balance sheet when it is probable that 
the future economic benefits [it represents] will flow to the entity and the asset has a cost or value that can be measured reliably' (Framework, paragraph B.89). A further criterion specified in the Framework is that such benefits must be under the exclusive control of the entity holding the asset. However, because of their nature, many heritage and cultural assets, fail to fulfil the requirements inherent in this definition. In many cases, the stewardship function of PBEs in regard to heritage and cultural assets falls short of the control criteria as it would apply to private ownership. Restrictive covenants often prevent PBEs from being able to sell or otherwise dispose of assets they hold. Rather than generating economic benefits, such assets often create obligations and cash outflows relating to preservation and maintenance costs (see, for example, Barton, 2000).

The title of the discussion paper, 'Heritage Assets: Can Accounting Do Better?' (ASB, 2006a), issued by the UK Accounting Standards Board (ASB), reflects the concerns generated from the present inconsistent accounting approach to the reporting of such assets. The difficulties intrinsic to the concept itself are evident in the various descriptions of such assets provided in the document 'Definitions of Heritage Assets', as an appendix to the ASB discussion paper. The description of heritage assets provided in the 2006 ASB discussion paper is drawn from the definition provided in IPSAS 17, Property Plant and Equipment, and states that heritage assets include, for example, historical buildings and monuments, archaeological sites, conservation areas and nature reserves, and works of art (IPSAS 17, paragraph 10), and comprise those 'assets with historic, artistic, scientific, technological, geophysical or environmental qualities that are held and maintained principally for their contribution to knowledge and culture and this purpose is central to the objectives of the entity holding them. As well as museum collections such as those of art, antiquities and books the term 'heritage assets' includes assets such as landscape and coastline, historic buildings and archaeological sites' (Preface, ASB, 2006a, paragraph 5).

The International Public Sector Accounting Standards (IPSAS) 'deal with issues related to the presentation of annual general purpose financial statements (GPFSs) of public sector reporting entities other than government business enterprises (GBEs) ... Users of GPFSs include taxpayers and ratepayers, members of the legislature, creditors, suppliers, the media, and employees. The objectives of GPFSs are to provide information useful for decision-making, and to demonstrate the accountability of the entity for the resources entrusted to it' (International Public Sector Accounting Standards Board (IPSASB), 2006, Introduction). Many public sector entities are required to provide information supplemental to financial statements, in the form of summary quantitative information related to organisational objectives and expected outcomes. In New Zealand, government sector entities are required to provide an annual Statement of Service Performance. This statement sets out an organisation's major areas of service provision (such as, in the case of a museum or art gallery, visitor numbers for the period and the number of new curated exhibitions), as well as 'key operating objectives', 'key performance measures', and 'outcomes'. This document is focused on providing information related to quantitative outputs (that is, those material outputs which can be objectively measured), not assessing qualitative outcomes relevant to cultural objectives.

Without a specific accounting standard for the treatment of HCA, since the 1980s there has been considerable variability and inconsistency in the accounting treatment applied to such assets. The discussion in a 2008 paper considering the appropriate treatment of heritage assets - 'Accounting for heritage assets under 
IFRS' (UK Treasury, 2008), issued by the Financial Reporting Advisory Board (FRAB) of the UK Treasury - illustrates the current dissension and lack of consistency in recommended approaches towards accounting for and disclosing such assets. The document advises that 'newly acquired assets are [to be] valued at cost; newly donated assets should be valued at market value'. It observes that, in practice, 'the guidance on non-operational heritage assets has been applied only to those assets acquired after 1 April 2001 (museums' and galleries' collections) or 1 April 2000 (central government departments), with collections in existence at those dates not being recognised in the relevant balance sheets' (UK Treasury, 2008, paragraph 2). In acknowledging the current inconsistencies in the treatment of non-operational heritage assets, the document recognises four alternative options in reporting and measuring such assets, and evaluates the merits of each (UK Treasury, 2008, paragraph 3). The document concludes with the statement that, given the present uncertainties and inconsistencies in accounting treatments, further views are sought 'on how the UK public sector should account for these assets' (UK Treasury, 2008, paragraph 3).

In New Zealand, the issue of accounting for HCA arises for all PBEs including local and central government entities holding such assets. PBEs are required under the provisions of the Public Finance Act 1989 (PFA) to recognise and report heritage assets in terms of GAAP, in a manner corresponding to the treatment of operational assets. The PFA states that: 'As cultural and heritage assets are for the continuing use of the library, museum, art galleries and other entities in the provision of services to the community, they are within the definition of PPE. It would be inappropriate to write off investments in cultural assets as a current expense, when the economic benefits will mainly emerge in the future' (NZ Treasury, 2002).

The problematic issue of accounting for HCA arises only for PBEs charged with the stewardship of such items; assets of an otherwise similar nature held by forprofit private sector entities (for example, works of art displayed for purposes of enhancement of corporate reputation and thereby indirectly attracting revenues), are treated as tangible or intangible PPE in accordance with the general PPE standards and guidelines.

Over the past decade, the set of IFRS developed and promulgated by the IASB have been adopted in full or part by most countries, including the major economies and many smaller nations. These standards, or their variants, were developed specifically to apply to large, for-profit, private sector entities that are 'reporting entities', with accountability obligations to stakeholders (particularly securityholders). In recognition of the difficulties of applying these standards to public sector and NFP entities, some countries have developed variants of these standards for separate application to PBEs (for example, the set of IPSAS). Currently NZ, like Australia, applies a single set of standards for all entities that are 'adapted' for application to PBEs. IPSAS, like IFRS, are focused primarily on providing economic information for statement users.

The 'fundamental qualitative characteristics' required for accounting information, outlined in the NZ Framework 2010 as it currently applies to PBEs (paragraphs BC3.32-BC3.43) include: Relevance (information is relevant if, by its inclusion or exclusion, it is 'capable of making a difference in the decisions made by users'); Faithful representation (information must 'represent faithfully the phenomena it purports to represent'); Comparability (information 'can be compared with similar information about other entities and with similar information about the same entity for another period or another date'); and Verifiability ('different knowledgeable and 
independent observers could reach consensus, although not necessarily complete agreement, that a particular depiction is a faithful representation'. Conventional approaches to PBE reporting in regard to HCA fail to provide information that meets these required qualitative characteristics of financial reporting. In the case of these entities, therefore, it cannot be claimed that this approach sufficiently meets the objective of the Framework that such information is useful for decision-making.

\section{Critiquing Conventional Approaches to Accounting for HCA}

It is recognised in accounting regulation that accounting for HCA may be a problematic exercise for PBEs including public sector entities. An Appendix to the NZ Framework 2010, for example, acknowledges that '[i]n the public benefit sector special consideration needs to be given to the reporting of assets that do not generate cash, where there is little market evidence, and where the provision of an asset or the supply of benefits arising from the asset are provided at non-market rates'. The Framework allows that the term 'future economic benefits', when applied in the case of PBEs, may be read as 'having the same meaning as the term "service potential"', so that '[a]ssets that are used to deliver goods and services in accordance with an entity's objectives but which do not directly generate net cash flows are often described as embodying "service potential"' (paragraph NZ B49.1). While not directly generating cash flows, however, service potential is to be similarly measured and reported in economic terms.

There is a significant body of literature that considers the concept of accountability as it applies to NFP organisations including public sector entities, NGOs, the charitable sector, and other organisations that aim to enhance civil society. While all agree that such entities should demonstrate 'accountability' to their stakeholders, there is strong dissension as to the form that such accountability should take. For example, Micallef and Peirson (1997) consider that it is necessary for public sector entities to provide financial statements, and for heritage and cultural assets to be assigned economic values, in order to effectively evaluate management accountability: 'Information about cultural, heritage, scientific and community collections ... held by museums, art galleries and libraries and controlled by public sector entities is necessary to make informed assessments about the allocation of (scarce) public funds, and any changes in the allocation of funds from period to period ... It is also part of the information necessary to assess whether the value of the assets controlled by the entity has been eroded, improved or retained, and for assessments of previous decisions to acquire [such assets]. In addition, including information about [such assets] in general purpose financial reports enables the managers of museums, art galleries and libraries to discharge their accountability by providing some of the information necessary to enable assessments of their performance' (Micallef \& Peirson, 1997, p34).

Others, however, question whether private sector models of disclosure and accountability are apposite for public entities (see for example, Ball \& Grubnic, 2008; Cooper \& Owen, 2007; O’Dwyer, 2003; Lehman, 1999 \& 2001; Leat, 1988; Jegers \& Lapsley, 2001; Easton, 1997; Gray \& Bebbington, 2006; Gray, Owen \& Adams, 1996; Edwards \& Hulme, 1995; Hofstede, 1981). Many question the assumptions, inherent in the NPM ideology, that the information requirements of stakeholders of public sector and other civil society organisations parallel that of the private sector, and dispute claims that models of accountability developed for profit-oriented, corporate entities are appropriate to the public sector. For example, Carnegie and 
Wolnizer (1995) dismiss the utility of imposing an economic value on cultural assets as being merely 'an accounting fiction' (p31).

In a study focused on the reporting practices of charitable organisations, Heslop and van Staden (2009) question the suitability of the for-profit reporting model for application in the NFP sector. They conclude that rather than a focus on decision usefulness, 'accountability should be the main theoretical basis for financial reporting by NFP entities' (pp42,43). Broadbent and Guthrie (1992) analyse the historical and current political motivations that have driven the decision to impose a private sector reporting model onto the public sector. They consider a range of alternative modes of reporting to satisfy accountability requirements that are appropriate for organisations whose goals are social and cultural, not profit-oriented. Drucker (1990), provides a survey of alternative models of communicating accountability to stakeholders for a range of NFP organisations. Pallot $(1987,1990)$ suggests that the separate recognition of a class of assets defined as 'community assets' - that is, publicly owned and accessible tangible and intangible assets - for which the accounting treatment should substantively differ from that of 'useful' assets for which revenue flows could feasibly be measured. Barton (1999b, 2005a) asserts that HCA should be accounted for off the balance sheet, as a category of 'public goods'.

A number of alternatives to conventional Western concepts of accounting have been proposed in studies of the accounting principles and practices of other cultures, including those of indigenous peoples (for example, McNicholas, 2009; Gallhofer et al, 2000; Mataira, 1994; Winiata, 1988, 2006). These include accountability in the case of assets, profit and wealth, which are substantively different from those inherent in the mode of accounting that has developed to serve a capitalist economic system based on maximising financial returns to private investors. These studies propose that it is not appropriate to apply conventional accounting to the measurement and reporting of non-commercial assets for organisations whose primary function is to meet social and cultural objectives, not economic goals.

Easton (1997) is negative in his assessment of the efficacy of NPM measures in achieving improved accountability in public sector entities. Considering the effects of implementing the new financial reporting regime on public sector entities, and evaluating its efficacy on improving accountability of such entities, Easton concludes that the real objectives of government in imposing such policies were political in nature, and directed at the commercialisation and divestment of publicly-held resources. He suggests that 'the valuations of heritage assets appear to have the same status as those of the commercial assets, a circumstance which leaves open the possibility that heritage assets could be treated as commercial assets and even privatised (Easton, 1997, p186).

In Easton's view, the actual achievement of government policies was to create the appearance rather than the actuality of imposing accountability on the public sector. Easton observes that 'clear outcomes' that could potentially provide an effective measure of 'accountability' were not determined, and that 'the hard notion of an output has been reduced to a warm fuzzy', such that measures do not allow 'a Parliament or minister ... to judge objectively the quantity (let alone quality) of such an output' (Easton, 1997, p175). Further, Easton considers that the imposition of inappropriate management policies into the public sector has been detrimental to their functioning, in imposing an irrelevant private sector model that distorts the effectiveness of their operations: 
How a game is scored affects the way it is played. A system dominated by commercial accounting practices with their emphasis on the measurement of profit is going to reduce the significance of activities that do not make a profit. Not surprisingly, government departments were pushed into corporatising and privatising their activities or contracting them out to the private sector. Those which remained were seen as cost centres, with the benefits of what was supplied tending to be neglected (Easton, 1997, p175).

\section{Accounting for Cultural Assets - An Alternative Metric from a New Zealand Māori Educational Institution}

The notion in Western accounting philosophy that concepts such as 'asset', 'value', 'wealth', 'wellbeing' and 'progress' are neutral in nature, and can be objectively evaluated in economic and other quantitative, positivist measures, has been strongly challenged in the literature (for example, McNicholas, 2009; Durie, 2006; Durie, et al, 2002; Gallhofer et al, 2000; Winiata, 1988, 2006; Mataira, 1994; Pallot, 1987, 1990, 1994, 2001; Carnegie \& Wolnizer, 1995, Carnegie \& West, 2005). The converse view - that such terms are highly subjective, strongly culturally-laden, and subject to social and political bias - is emphasised in the literature focused on these concepts in indigenous and other cultures, including studies provided by New Zealand Māori scholars (see, for example, Mataira, 1994; Winiata, 1988, 2006; Te Puni Kokiri, 2000; Durie, 2006).

In a lecture to the NZ Treasury entitled 'Measuring Māori Wellbeing', influential Māori education and health academic Sir Mason Durie (2006, p14) outlines a set of principles for the development of non-quantitative measures for the evaluation of organisational cultural objectives and outcomes. Durie is Professor of Māori Research and Development at Massey University, and is affiliated with the Ngati Raukawa, Ngati Kauwhata and Rangitane Māori tribes. He proposes a dichotomised approach to constructing measures of 'value' that use a 'universal' perspective and a 'population-specific' perspective (or 'individual group dimension'), and asserts that in order to apply to an organisation an appropriate process of evaluation in regard to a particular qualitative characteristic (in this case, 'Māori wellbeing') it is essential to develop and engage multiple, relevant measurement indicators:

Because there is no single indicator that can accurately reflect the state of Māori wellbeing, more than one set of indicators should be employed. The sole use of narrow single-dimension measures ignores the several dimensions of Māori wellbeing. For individuals those dimensions reflect spiritual, physical, mental and social parameters; while for whannau [extended family group] they include the capacity for caring, planning, guardianship, empowerment, cultural endorsement, and consensus. For the Māori population as a whole, measurements than can gauge the overall wellbeing of human capacity (individuals and groups) and resource capacity (intellectual and physical resources), are necessary. Some of these measurements will employ economic measures, others will be measures of social and cultural capital, and others will be linked to measurements of environmental sustainability (Durie, 2006, p14). 
Durie identifies a taxonomy of six primary 'capacities', based on qualities that stakeholders have proposed as being key determinants of Māori wellbeing. These are: 'the capacity to care; the capacity for guardianship; the capacity to empower; the capacity for long-term planning; the capacity to endorse Māori culture, knowledge and values, and the capacity for consensus' (Durie, 2006, p4). Durie's assertions emphasise the view that reporting financial measures of value alone is insufficient for the purpose of providing adequate information for the full range of decision-making purposes of the stakeholders of organisations with cultural objectives. The measures Durie proposes are context-specific, use a range of both qualitative and quantitative indicators, and focus on decision-usefulness in its broad sense.

Similarly, Whatarangi Winiata, in his paper, 'Measuring Wellbeing of Communities: Hapū, Iwi, Regions and Nations' (2006), sets out an alternative set of valuation metrics to apply to the governance and management of a Māori educational institution. Winiata, a Māori academic affiliated to the Ngāti Raukawa tribe, is a professor and former chief executive of New Zealand Māori educational institution Te Wānanga-o-Raukawa. This institution represents itself as being 'a unique centre of higher learning devoted to the world of Māori knowledge (Mātauranga Māori). Te Wānanga-o-Raukawa is a reformulation of an ancient Polynesian institution known as the whare wānanga, which were tribal centres of higher learning' (Te Wānanga-oRaukawa, website).

Winiata's 2006 study outlines the development of an alternative, contextspecific and culturally relevant set of 'genuine progress indicators [that] relate to a community', for the purpose of measuring appropriately and usefully the performance of Māori organisations in managing their collectively-held taonga (treasures; anything highly prized) for the benefit of their members (Winiata, 2006). The primary foci of 'Measuring Wellbeing' are its challenge to the dominant conventional economic assumption that the concept of human 'wellbeing' is synonymous with positive economic measures alone, and its assertion of an alternative definition of 'wellbeing':

Whereas in finance and economics, the theory of the firm starts with the assumption that firms seek to maximise their financial wealth, this is not the case with hapu $\bar{u}$ [sub-tribe]. The assumption that hap $\bar{u}$ will behave to maintain and enhance their mana-a-hapu $\bar{u}$ [tribal prestige] will lead to more reliable predictions about hapū and iwi [tribe] behavior than the competing starting assumption (Winiata, 2006, n.p.).

Reports are presented and defended verbally by management at a number of tribal hui (gatherings, formal meetings), where all members of the iwi, hapu and whānau are invited to be present and to participate. In this way, Te Wānanga-oRaukawa management are publicly accountable to all of the organisation's stakeholders at all levels, and are required to account directly for policies and decision-making processes and outcomes. Emphasis is given to reporting on cultural measures, achievements and strategies, with mandatory financial reporting accorded secondary status. 
An important indicator is the measure of mana-a-hapu. Winiata, (2006, n.p.), n.p.describes this condition as being 'the favourable view that others hold of the hapū, particularly other roppu tuku iho [groups of visitors, important parties of guests] and is the result of (a) the quality of the management of the affairs of the hapū, and (b) the ability of the hapū and its demonstrated willingness to extend generosity to its own members and to others, especially to rōpū tuku iho'.

These attributes are ascribed among tribes by other hapū: 'The more favourably a hapū is viewed, the greater is its mana-a-hapū within the community of hap $\bar{u}$ and iwi. The less favourable is the view, the lower its mana-a-hap $\bar{u}$ among its counterparts.' Mana-a-hapu could therefore be translated approximately as being 'the status, prestige, and high standing in which the community group is held by others, due to its good conduct'. An important quality inherent in the definition of hapū, and one that is 'given prominence', is that it 'looks to maintain (and enhance) its mana-ahapū in its activity' (Winiata, 2006, n.p.).

As measures of the effectiveness of management in regard to the affairs of the hapū and iwi, Winiata (2006, n.p.) proposes seven key indicators:

- Active membership (participation)

- Kaumātua (elders)

- Pātaka (storehouse)

- Whakapapa (genealogy)

- Te reo (Māori language proficiency)

- Mātauranga (education)

- Marae facilities (meeting ground and associated buildings).

These broad indicators establish benchmark attributes from which a set of qualitative and quantitative metrics can be developed and used as measures of accountability and achievement of the organisation's aims and objectives. These indicators relate respectively to: the extent of participation of hapu and iwi members, and in particular of tribal elders, who are actively engaged in the decision-making processes of the operational and strategic management of Te Wānanga-o-Raukawa; the concept of pâtaka relates to the extent of the organisation's underpinning in tikanga Māori (Māori customs and protocols), and the specific cultural outputs that it produces, archives (stores) and promulgates; levels of proficiency in te reo (Māori language) and tikanga Māori in graduates of Te Wānanga-o-Raukawa's programs; level of increase in Māori-based educational programs; and the standard and quality of the tangible facilities provided by Te Wānanga-o-Raukawa, including teaching and community buildings. The importance and essential nature of these qualities, not only to effective governance but to the long-term sustainability ('survival') of Māori communities, is emphasised.

Further explication of particular performance indicators of mana-a-hapū are provided in Winiata's study. These include:

- Generosity extended by an iwi or hapū. Generosity extended by a hapū to another rōpū reflects an attitude of mind toward generosity. It will be constrained by the ability of the hapu to deliver, and recipients of the generosity will be mindful of this. Generosity can take many forms. Some examples are: assistance with building and other projects; cash, food or other contributions to events; spiritual support at ceremonies. 
- Utu or reciprocity. Generosity extended by one hapū to rōpū tuku iho will be met by utu or reciprocity, that is, generosity returned. Failure to express utu or reciprocity on an appropriate occasion will affect adversely the view of the giver of the generosity toward the receiver of the generosity (Winiata, 2006, n.p.).

In Winiata's view, effective and useful assessment of the accountability of Te Wānanga-o-Raukawa towards its stakeholders - including all members of the affiliated tribes with a present and future interest in the graduates (of the Māori tertiary education institution) - can be achieved not by means of the conventional economic measures inherent to Pakeha (non-Māori) culture, but through a range of culturally-appropriate and effective measures of outcomes related to the organisation's aims. Winiata acknowledges that these measures were specifically developed for application to Te Wānanga-o-Raukawa as no appropriate existing models were available. These metrics, incorporating cultural, environmental and social as well as economic values, provide stakeholders with useful information with which to measure accountability against the specific outcomes established by the objectives of the organisation. These values form a contextual matrix that prioritises long-term over short-term objectives, inter-generationality, communitarian over individual ownership, and emphasises the permanent community utility of cultural assets, rather than their economic value, fungibility and transferability (see, for example, Craig, et al, 2012).

In a document on its public website, Te Wānanga-o-Raukawa sets out its 'Vision Statement', entitled Guiding Kaupapa of Te Wānanga-o-Raukawa. ${ }^{2}$ This statement outlines the 'policy base for the Wānanga to guide its decision-making', setting out 'what constitutes a tikanga Māori institution' and discusses the set of principles that underlie the Kaupapa Māori management practices which 'not only relate to personnel policies and practices, but rather the whole modus operandi of the institution', so that 'Mātauranga Māori [Māori knowledge] is the foundation for our contemplations, developments and future' $(\mathrm{p} 1,2)$. The charter summarises ten 'models' that identify and apply mātauranga Māori, and which form the foundation for all the Wānanga's operations, methods, processes and policies. It demonstrates the alignment and interrelationship of the Wānanga's tikanga (methods, processes and policies), with its kaupapa (principles, values, philosophies), and with the Aronga (Māori World View), a paradigm that acts as the conceptual framework for the development of a tikanga Māori institution such asTe Wānanga-o-Raukawa. In this model, the resources of the institution, including its tangible and intangible heritage and cultural assets, are valued not in accordance with conventional 'Pākeha methodology and principles', but on the basis of their contribution towards the organisation’s Kaupapa Māori (p2).

\section{Conclusions}

The introduction of market mechanisms into the management of the public sector in the 1980s and 1990s fundamentally changed the manner in which PBEs were required to account for the HCA they held. New legislation imposed an obligation for such entities to provide financial statements prepared in accordance with accounting

\footnotetext{
${ }^{2}$ This document is subtitled: Kia rangatira te tū a Te Wānanga-o-Raukawa hei whare ako, whakatupu hoki i te mātauranga.
} 
standards and GAAP, which included the requirement that all heritage, cultural and community assets were to be valued in financial terms.

Imposing a requirement that all public sector agencies record and value all of their assets had the effect of bringing those holdings more tightly under government control. In 2002, the NZ Treasury asserted that 'Members of Parliament, Councillors, the public or ratepayers are entitled to know the extent of the resources ... allocated ... to the cultural institutions' (NZ Treasury, 2002). In requiring that an economic valuation should be imposed on all HCA, there was an implicit assumption that the treatment and measurement of accountability for these assets should be directed towards economic rather than social objectives.

There exists a large body of literature focused on the complex nature of the concept 'accountability' as it is applied in the context of PBEs and other NFP entities. It is broadly accepted in the literature that PBEs charged with the stewardship of HCA should be accountable in some form to their stakeholders for the achievement of the aims and objectives established for particular entities (for example, O'Dwyer, 2008; Easton, 1997, 2002; Ball \& Grubnic, 2008; Barton, 1999b; Booth \& Peterson, 1982; Carnegie \& Wolnizer, 1996; Carnegie \& West, 2005; Cooper \& Owen, 2007; Edwards \& Hulme, 1996; Gray, 1983; Gray \& Bebbington, 2006; Guthrie, 1993). Such entities are often responsible for holdings that represent very significant economic, heritage, and cultural values, and should be subject to measures of their accountability for such holdings, in the interests of the societies within which such entities operate. However, the particular form in which such accountability should be measured in the case of PBEs is strongly disputed.

The NPM model of accountability is focused on market-based imperatives, economic values, short-term returns of capital invested, and financial profit. This paper argues that it is inappropriate to apply the NPM model to entities whose purpose and goals are directed primarily towards social, cultural, community, educational and heritage outcomes - and on the stewardship of HCA for achieving these purposes. For example, the NPM model is antithetical to the goals of a tikanga Māori focused organization such as Te Wānanga-o-Raukawa, which prioritises a range of non-economic objectives and outcomes measured against its own metrics of cultural and social achievement.

The reporting framework for private sector entities provided in GAAP and IFRS/IPSAS is inappropriate for many public sector entities, and in particular for those that are focused on cultural outcomes and the stewardship of HCA. Instead, a framework of relevant cultural measures, analogous to the model developed for Te Wānanga-o-Raukawa outlined above, with outcomes defined specifically to measure the social and cultural aims inherent in such organisations, should be developed for wider application. Such frameworks should be supplemental to, or substituted for, the current requirements for annual financial statements currently applied to all public sector organisations.

Drawing on Durie's (2006) and Winiata's (2006) findings, this paper proposes that the basic assumptions outlined in 'Measuring Wellbeing of Communities', for the specific application to a Māori educational institution such as Te Wānanga-oRaukawa, could be adapted and broadly generalised to apply to the wider context of all PBEs holding HCA. This could be achieved by imposing a regulatory requirement that such organisations develop a set of comparable, culturally-appropriate measuring and reporting indicators, in conjunction with broad stakeholder consultation and engagement, and corresponding to organisation-specific cultural aims and objectives. Such cultural indicators would serve as an applicable, qualitative, non-economic 
metric for the purpose of providing an appropriate and useful means of measuring and reporting accountability towards stakeholders in regard to those entities.

Because of the intangible values inherent in HCA, the nature of the social and cultural aims and goals of PBEs, and the types of information needs of the users of the reports of such entities, the model of financial reporting applicable to private sector for-profit entities is not useful, reliable, understandable, or relevant. Further qualities required by the Framework for disclosures in entities' financial statements are that such information should be 'consistent' and 'comparable'. However, because of the necessarily arbitrary nature of the majority of the valuations ascribed to HCA, it cannot be claimed that such information conforms to the essential accounting qualities of consistency and comparability in reported information. The economic values assigned to many of the heritage assets in HCA collections are essentially arbitrary in nature, and cannot be considered to provide information useful for users' decisionmaking purposes.

O'Dwyer (2008) points out that while performance and accountability in the case of for-profit entities are commonly measured against the single performance indicator of the maximisation of shareholder wealth, calculated in economic values, evaluating performance and accountability is often considerably more complex for NFP entities, which 'encounter oft-competing demands of multiple constituencies' (O’Dwyer, 2008, p288). The attempt to impose a single, market-based measure of accountability onto PBEs, for which such an indicator may be largely irrelevant in terms of their societally-oriented goals, fails to fulfill the primary function of organisational reporting - that it provides information that is useful to stakeholders. However, current conventional methods of accounting for heritage assets, such as those promulgated by the International Public Sector Accounting Standards Board (IPSASB), UK Accounting Standards Board (UKASB), Association of Chartered Certified Accountants (ACCA), New Zealand Treasury, the External Reporting Board (XRB), and other accounting and regulatory bodies, advocate that PBEs should provide financial statements on a basis analogous to the for-profit model, with the requirement that all HCA should be disclosed at an economic value.

As an alternative approach, drawing on Durie's (2006) and Winiata's (2006) findings, this paper proposes that a set of comparable indicators could be developed, corresponding to the cultural aims and objectives of PBEs charged with the management of HCA, for the purpose of providing an appropriate and useful means of measuring accountability in regard to those entities. Further, it suggests that a category of 'community assets', incorporating public HCA, as suggested by Pallot (1990), should be adopted and included in a reporting framework for the purpose of fulfilling such an accountability function.

This paper argues that the conventional methods of financial reporting in the case of HCA fail to provide information to stakeholders that conforms to the qualitative characteristics of 'usefulness' set out in the NZ Framework, particularly in the case of measuring and reporting non-operational cultural assets. Instead, an alternative framework of relevant measures of accountability, that are communityoriented and comparable in quality and usefulness to those provided in 'Measuring Wellbeing of Communities' (Winiata, 2006), should be developed to apply to PBEs that are charged with the stewardship of cultural assets. Further research is required to develop a set of generally applicable principles that would provide the framework for such a metric of specific and context-sensitive cultural values that could be applied to the case of other PBEs. 
Wild: Accounting for HCAs in New Zealand

The author gratefully acknowledges the research assistance provided by Lesley Udy in the initial stages of preparation of this paper.

\section{References}

Accounting Standards Board (ASB) 2006a. Heritage Assets: Can Accounting Do Better?, ASB, London.

Accounting Standards Board (ASB) 2006b. Financial Reporting Exposure Draft No.40: Accounting for Heritage Assets, ASB, London.

Association of Chartered Certified Accountants (ACCA) 2006. ACCA Public Sector Network Panel, Accounting for Heritage Assets under the Accrual Basis of Accounting, June 2006. Accessed 1 August 2010 at: http://www.accaglobal.com/general/activities/policy_papers/archive/public/cdr610

Australian Central Territory Government (ACT) 2008. ACT Accounting Policy: Heritage and Cultural Assets, Accessed 1 August 2010 at: http://www.treasury.act.gov.au/accounting/html/accounting.htm

Ball, A \& Grubnic, S 2008. 'Sustainability accounting and accountability in the public sector', in Unerman, J, Bebbington, J \& O’Dwyer, B, Sustainability Accounting and Accountability, Routledge, Abingdon, UK, pp243-265.

Barton, A 1999a. 'Public and private sector accounting - the non-identical twins', Australian Accounting Review, vol.9, no.2, pp22-31. http://dx.doi.org/10.1111/j.18352561.1999.tb00105.x

Barton, A 1999b. 'A trusteeship theory of accounting for natural capital asset', Abacus, vol.35, no.2, pp207-222. http://dx.doi.org/10.1111/1467-6281.00041

Barton, A 2000. 'Accounting for public heritage facilities - assets or liabilities of the government?', Accounting Auditing and Accountability Journal, vol.13, no.2, pp219235. http://dx.doi.org/10.1108/09513570010323434

Barton, A 2002. 'Public sector accounting - a common reporting framework?', Australian Accounting Review, vol.12, no. 3, pp41-48.

Barton, A 2005a. 'The conceptual arguments concerning accounting for public heritage assets', Accounting Auditing and Accountability Journal, vol.18, no.3, pp434-439. http://dx.doi.org/10.1108/09513570510600774

Barton, A 2005b. 'Professional accounting standards and the public sector - a mismatch', Abacus, vol.41, no.2, pp138-158. http://dx.doi.org/10.1111/j.1467-6281.2005.00173.x

Booth, P \& Peterson, H 1982. 'External financial reports: necessary but not sufficient for the accountability of non-business organizations', Accounting Forum, March, pp13-21.

Boston, J, Martin, J, Pallot, J \& Walsh, P 1996. Public Management: The New Zealand Model, Auckland, Oxford University Press.

Broadbent, J \& Guthrie, J 1992. 'Changes in the public sector: a review of recent "alternative” accounting research', Accounting, Auditing and Accountability Journal, vol.5, no.2, pp3-31. http://dx.doi.org/10.1108/09513579210011835

Carlin, T 2005. 'Debating the impact of accrual accounting and reporting in the public sector', Financial Accountability and Management, vol.21, no.3, pp309-336. http://dx.doi.org/10.1111/j.0267-4424.2005.00223.x

Carnegie, G \& West, B 2005. 'Making accounting accountable in the public sector', Critical Perspectives on Accounting, vol.16, no.7, pp905-928.

http://dx.doi.org/10.1016/j.cpa.2004.01.002

Carnegie, G D \& Wolnizer, P W 1995. 'The financial value of cultural, heritage and scientific collections: an accounting fiction', Australian Accounting Review, vol.5, no.9, pp3147. http://dx.doi.org/10.1111/j.1835-2561.1995.tb00164.x

Carnegie, G D \& Wolnizer, P W 1996. 'Enabling accountability in museums', Accounting, Auditing \& Accountability Journal, vol.9, no.5, pp84-99. http://dx.doi.org/10.1108/09513579610151962

Carnegie, G D \& Wolnizer, P W 1997. 'The financial reporting of publicly-owned collections: whither financial (market) values and contingent valuation estimates?', Australian Accounting Review, vol.7, no.13, pp44-50. http://dx.doi.org/10.1111/j.1835-2561.1997.tb00027.x 
Carnegie, G D \& Wolnizer, P W 1999. 'Unravelling the rhetoric about the financial reporting of public collections as assets', Australian Accounting Review, vol.9, no.17, pp16-21. http://dx.doi.org/10.1111/j.1835-2561.1999.tb00095.x

Cooper, S \& Owen, D 2007. 'Corporate social reporting and stakeholder accountability: The missing link', Accounting, Organizations and Society, vol.32, no. 7-8, pp649-667. http://dx.doi.org/10.1016/j.aos.2007.02.001

Craig, R, Taonui, R \& Wild, S 2012. 'The concept of taonga in Māori culture: insights for accounting'. Accounting, Auditing \& Accountability Journal, vol. 25, no. 6, pp 10251047. http://dx.doi.org/10.1108/09513571211250233

Currie, B 1987. 'Accounting for public infrastructure assets', Public Finance and Accountancy, vol 8, pp7-10.

Davis, $N$ 2010. 'Accrual accounting and the Australian public sector - a legitimation explanation', Australasian Accounting Business and Finance Journal, vol.4, no.2, pp61-78.

Drucker, P 1990. 'The third sector: America's non-market counterculture', New Perspectives Quarterly, vol.7, no.2, pp49-51.

Durie, M 2006. Measuring Māori Wellbeing. New Zealand Treasury, Guest Lecture Series 2006. Accessed 1 August 2010 at: http://www.treasury.govt.nz/publications/mediaspeeches/guestlectures/pdfs/tgls-durie.pdf

Durie, M, Fitzgerald, E, Kingi, Te K, McKinley, S \& Stevenson, B 2002. Māori Specific Outcomes And Indicators: A Report Prepared For Te Puni Kōkiri, the Ministry Of Māori Development. School of Māori Studies, Massey University, Palmerston North.

Easton, B 1997. The Commercialisation of New Zealand. Auckland, Auckland University Press.

Easton, B 2002. Valuation Guidance For Cultural and Heritage Assets. Review of report prepared by the Treasury Accounting Policy Team, for The Treasury November 2002. Accessed 15 September 2010 at: http://www.eastonbh.ac.nz/

Edwards, M \& Hulme, D 1996. NGO Performance and Accountability: Beyond the Magic Bullet. Kumarian Press, West Hartford, Connecticut.

External Reporting Board Te Kāwai Ārahi Pūrongo Mōwaho (XRB) 2011. Accounting Standards Framework for General Purpose Financial Reporting by Public Benefit Entities. Consultation Paper. XRB, Wellington.

External Reporting Board Te Kāwai Ārahi Pūrongo Mōwaho (XRB) 2012. Proposals for the New Zealand Accounting Standards Framework. Accessed 31 March 2012 at: http://xrb.govt.nz/Site/Financial_Reporting_Strategy/Accounting_Standards Framew ork.aspx

Feigenbaum, H \& Henig, J 1994. 'The Political underpinnings of privatization: a typology', World Politics, vol.46, no.2, pp185-208. Accessed 1 August 2010 at: http://www.jstor.org/stable/2950672

Financial Reporting Act 1993 (FRA). Accessed 31 July 2012 at: http://www.legislation.govt.nz/act/public/1993/0106/latest/DLM323598.html

Financial Reporting Standards Board of the New Zealand Institute of Chartered Accountants 2004. New Zealand Equivalent to International Accounting Standard 16: Property Plant and Equipment (NZIAS 16). Accessed 31 March 2012 at: http://www.xrb.govt.nz/Site/Accounting_Standards/ Current_Standards/old_framework/Standards_for_PBE_Entities.aspx

Gallhofer, S, Gibson, K, Haslam, J, McNicholas, P \& Takiari, B 2000. 'Developing environmental accounting: insights from indigenous cultures', Accounting, Auditing and Accountability Journal, vol.13, no.3, pp38-409. http://dx.doi.org/10.1108/09513570010334937

Gray, R 1983. 'Accountability, financial reporting and the not-for-profit sector', British Accounting Review, vol.15, no.1, pp3-23.

Gray, R, Owen, D \& Adams, C 1996. Accounting and Accountability. Prentice-Hall, London. 
Gray, R \& Bebbington, J 2006, 'NGOs, civil society and accountability: making the people accountable to capital', Accounting, Auditing and Accountability Journal, vol.19, no.3, pp319-348. http://dx.doi.org/10.1108/09513570610670325

Guthrie, J 1993. 'Australian public business enterprises: analysis of changing accounting, auditing and accountability regimes', Financial Accountability and Management, vol.9,no.2, pp101-114. http://dx.doi.org/10.1111/j.1468-0408.1993.tb00102.x

Guthrie, J 1998. 'Application of accrual accounting in the Australian public sector - rhetoric or reality?', Financial Accountability and Management, vol.14, no.1, pp1-19. http://dx.doi.org/10.1111/1468-0408.00047

Heslop, J \& van Staden, C 2009. 'Implications of applying a private sector based reporting model to not-for-profit entities: the treatment of charitable distributions by charities in New Zealand', Australian Accounting Review, vol.19, no.1, pp42-53. http://dx.doi.org/10.1111/j.1835-2561.2008.00039.x

Hofstede, G 1981. 'Management control of public and not-for-profit activities', Accounting, Organizations and Society, vol.6, no.3, pp193-211. http://dx.doi.org/10.1016/03613682(81)90026-X

Hone, P 1997. 'The financial value of cultural, heritage and scientific collections: a public management necessity', Australian Accounting Review, vol.7, no.13, pp38-43. http://dx.doi.org/10.1111/j.1835-2561.1997.tb00026.x

Hooper, K C \& Kearins, K N 2005. 'Knowing "the price of everything and the value of nothing”: accounting for heritage assets', Accounting, Auditing and Accountability Journal, vol.18, no.3, pp410-433. http://dx.doi.org/10.1108/09513570510600765

Huggins, J 1983. 'Local body accounting could use depreciation accounting', Accountants Journal, vol.62, no.4, pp181-184.

International Accounting Standards Board (IASB) 2010. IASB Conceptual Framework for Financial Reporting, Accessed 1 August 2010 at: http://www.iasb.org/NR/rdonlyres/4CF78A7B-B237-402A-A031709A687508A6/0/Framework.pdf

International Public Sector Accounting Standards Board (IPSASB) 2006. IPSAS 17, Property Plant and Equipment. Accessed 31 May 2012 at: https://www.ifac.org/sites/default/files/publications/files/A25_IPSAS_17.pdf

Jacobs, K 2000. 'Evaluating accountability: finding a place for the Treaty of Waitangi in the New Zealand public sector', Accounting, Auditing and Accountability Journal, vol.13, no.3, pp360-380. http://dx.doi.org/10.1108/09513570010334919

Jegers, M \& Lapsley, I 2001. ' Making sense of non-profit organizations', Financial Accountability and Management, vol.17, no.1, pp1-3. http://dx.doi.org/10.1111/1468$\underline{0408.00117}$

Kay, J A \& Thompson, D J 1986. 'Privatization: a policy in search of a rationale', The Economic Journal, vol.96, no.2, pp18-32. http://dx.doi.org/10.2307/2233423

Kelsey, J 1995. The New Zealand Experiment: A World Model for Structural Adjustment. Auckland University Press, Auckland. http://dx.doi.org/10.7810/9781869401306

Leat, D 1988. Voluntary Organisations and Accountability. National Council for Voluntary Organisations, London.

Lehman G 1999. 'Disclosing new worlds: a role for social and environmental accounting and auditing', Accounting, Organizations and Society, vol.24, no.3, pp217-241. http://dx.doi.org/10.1016/S0361-3682(98)00044-0

Lehman G 2001. 'Reclaiming the public sphere: problems and prospects for corporate social and environmental accounting', Critical Perspectives on Accounting, vol.12, no.6, pp713-733. http://dx.doi.org/10.1006/cpac.2001.0476

Local Government Act 2002 (LGA). Accessed 21 January 2013 at: http://www.legislation.govt.nz/act/public/2002/0084/latest/DLM170873.html

Mataira, K 1994. 'Accountability in Māori society', Chartered Accountants Journal, February 1994, pp32-33.

McNicholas, P 2009. 'Māori development: “accounting”, “accountability” and participation in the accountancy profession’, Pacific Accounting Review, vol.21, no.3, pp319-324. http://dx.doi.org/10.1108/01140580911012539 
Mautz, R K 1981. 'Financial reporting: should government emulate business?', Journal of Accountancy, vol.152, no.2, pp53-60.

Micallef, F \& Peirson, G 1997. 'Financial reporting of cultural, heritage, scientific and community collections', Australian Accounting Review, vol.7, no.13, pp31-7. http://dx.doi.org/10.1111/j.1835-2561.1997.tb00025.x

Ministry of Economic Development (MED) 2009. Discussion Document: The Statutory Framework for Financial Reporting. Accessed 23 March 2010 at: http://www.med.govt.nz/templates/MultipageDocumentTOC_ 41975.aspx

New Zealand Treasury, NZ Treasury Accounting Policy Team 2002. Valuation Guidance for Cultural and Heritage Assets. Accessed 15 September 2010 at: http://www.treasury.govt.nz/publications/guidance/reporting/accounting/cultural

O’Dwyer, B 2003. 'Conceptions of corporate social responsibility: the nature of management capture', Accounting, Auditing and Accountability, vol.16, no.4, pp523-557. http://dx.doi.org/10.1108/09513570310492290

O’Dwyer, B 2008. 'The nature of NGO accountability', in Unerman, J, Bebbington, J \& O’Dwyer, B, Sustainability Accounting and Accountability, Routledge, Abingdon, UK, pp285-306.

Pallot, J 1987. 'Are public sector assets different?’, Accountants Journal, May, pp41-45.

Pallot, J 1990. 'The nature of public assets', Accounting Horizons, June, p79-85.

Pallot, J 1992. 'Elements of a theoretical framework for public sector accounting', Accounting, Auditing and Accountability, vol.5, no.1, pp38-59. http://dx.doi.org/10.1108/09513579210008244

Pallot, J 1994. 'The development of accrual based accounts for the government of New Zealand', Advances in International Accounting, vol.7, pp287-308.

Pallot, J 2001. 'A decade in review: New Zealand's experience with resource accounting and budgeting', Financial Accountability and Management, vol.17, no.4, pp383-400. http://dx.doi.org/10.1111/1468-0408.00140

Public Finance Act 1989 (PFA). Accessed 9 March at: 2013http://www.legislation.govt.nz/act/public/1989/0044/latest/whole.html\#DLM163 173

Rowles, T 1991. 'Infrastructure and heritage asset accounting', Australian Accountant, vol.61, no.6, pp69-74.

Stanton, J \& Stanton, P 1997. 'Governmental accounting for heritage assets: economic, social implications', International Journal of Social Economics, vol.24, no.9, pp988-1006. http://dx.doi.org/10.1108/03068299710178973

State Sector Act 1988. Accessed 30 August 2012 at: http://www.legislation.govt.nz/act/public/1988/0020/latest/whole.html\#DLM130706

Te Puni Kokiri 2000. A Framework for Measuring Māori Development: Working Paper One. Ministry of Māori Development, Wellington.

Te Wānanga-o-Raukawa (n.d.). Guiding Kaupapa of Te Wānanga-o-Raukawa. Accessed 1 August 2012 at: http://www.wananga.com/images/pdf/Guiding_Kaupapa.pdf

Thompson, G D 1998. 'Cultural capital and accounting', Accounting Auditing and Accountability Journal, vol.12, no.4, pp394-492. http://dx.doi.org/10.1108/09513579910283440

UK Treasury, Financial Reporting Advisory Board (2008). Accounting for Heritage Assets under IFRS. Accessed 1 August 2010 at: http://www.hm-treasury.gov.uk/d/frab91 accountingheritageassets.pdf

West, B \& Carnegie, G 2010. 'Accounting's chaotic margins: financial reporting of the library collections of Australia's public universities, 2002-2006', Accounting, Auditing and Accountability Journal, vol.23, no.2, pp201-228.

Winiata, W 1988. 'Hapu and Iwi resources and their quantification', Royal Commission of Social Policy - April Report, vol.3, no.2, pp791-803.

Winiata, W 2006. Measuring Wellbeing of Communities: Hapū, Iwi, Regions and Nations. Accessed 15 July 2010 at: http://www.wananga.com/docs/pdfs/Papers\%20by\%20Whatarangi\%20Winiata.pdf 